\title{
SEA-SURFACE TEMPERATURE EFFECTS ON 3D BORA-LIKE FLOW
}

\author{
${\text { Lukša Kraljević }{ }^{1} \text {, Branko Grisogono }}^{2}$ \\ ${ }^{1}$ Meteorological and Hydrological Service of Croatia, Grič 3, 10000 Zagreb, Croatia \\ ${ }^{2}$ Department of Geophysics, Faculty of Science, Horvatovac bb, 10000 Zagreb, Croatia \\ E-mail: kraljevic@cirus.dhz.hr
}

\begin{abstract}
A COAMPS (TM) nonhydrostatic numerical model with a higher order turbulence closure scheme is used to study the effect of the sea surface temperature (SST) on the idealized nonlinear flow over an idealized mountain in the presence of rotation. The low-level jet (LLJ) that develops at both flanks of the mountain is intensified by the Coriolis effect on the northern flank for a westerly flow. Shooting flow develops down the slope ending over the sea while resembling a hydraulic jump. This is considered as bora (bura) like flow. The front is related to the abrupt slowdown of the shooting flow through the hydraulic jump. Seven different idealized cases are addressed, the control run, linear case with $\mathrm{Fr}=1.2$, and the cases with the SST $10 \mathrm{~K}$ colder, and $2.5 \mathrm{~K}, 5 \mathrm{~K}, 7.5 \mathrm{~K}$ and $10 \mathrm{~K}$ warmer than the control run. The maximum wind speeds in the shooting flow and the LLJs are around two times higher than the background wind speeds. The interplay of SST effects and the effects of the asymmetric lee-side vortices modify the location and the shape of the bora front which is found not to be parallel with the shoreline. The front is not stationary in time but exhibits vibrations which are more pronounced at the southern flank associated with the weaker LLJ.
\end{abstract}


Zusammenfassung: Mit Hilfe von COAMPS (TM), einem nichthydrostatischen numerischen Modell mit einem Turbulenz-Schließungsschema höherer Ordnung, wurden Auswirkungen der Meeresoberflächentemperatur auf eine idealisierte nichtlineare Strömung über einem idealisierten Gebirge unter Vorhandensein von Rotation untersucht. Aufgrund des Coriolis-Effektes wird der Low Level Jet (LLJ), welcher sich auf beiden Seiten des Gebirges bildet, bei westlicher Strömung auf der Nordseite verstärkt. Eine schießende Strömung ergießt sich den Hang hinunter und wird über dem Meer, ähnlich einem hydraulischen Sprung, rasch abgebremst. Diese Strömung ähnelt einer Bora. Sieben verschiedene idealisierte Fälle wurden durchgerechnet: ein Kontrolllauf, ein linearer Fall mit $F r=1.2$, und Fälle mit einer um $10 \mathrm{~K}$ tieferen sowie um $2.5 \mathrm{~K}, 5 \mathrm{~K}, 7.5 \mathrm{~K}$ und $10 \mathrm{~K}$ höheren Meeresoberflächentemperatur. Die höchsten Windgeschwindigkeiten innerhalb der schießenden Strömung und des LLJs sind etwa doppelt so groß wie in der Umgebung. Auswirkungen der Meeresoberflächentemperatur und leeseitiger Wirbel verändern die Position und Form der Borafront, die nicht parallel zur Küste verläuft. Die Front ist zeitlich nicht stationär und zeigt Schwankungen, die an ihrem südlichen Ende mit einem schwächeren LLJ stärker ausgeprägt sind.

Keywords -Sea surface temperature, Bora, Downslope wind, Numerical modeling, Low-level jet

\section{INTRODUCTION}

Bora (local: 'bura') is a strong, gusty, north-easterly downslope wind which occurs along the eastern Adriatic coast. It is common during the winter, but it can also happen in the summer although with lower intensity and shorter duration. During situations with very strong bora, the gust speed may exceed $60 \mathrm{~m} \mathrm{~s}^{-1}$. Needless to say, its influence on traffic is great during such severe episodes. Bora is a representative of a 
class of downslope windstorms and dynamically bears similarity with Boulder windstorms (SMITH 1987) as well as with chinook and foehn (e.g. DURRAN 2003) and other downslope winds on other orographically similar places. Situation favorable for bora occurrence is characterized by the strong pressure gradients between an anticyclone over north-eastern Europe and a depression located over the middle or the western Mediterranean, or by a pool of cold air located over inland Croatia and a cyclone developing over the western Mediterranean (PoJe 1992).

The basic theory of bora flows is given by Sмiтн $(1985,1987)$, SмIтн and Sun (1987) relating bora-like flows to the hydraulic theory. DurRan (1986) showed that wave breaking and an elevated inversion are important in producing supercriticality of the flow predicted by hydraulic theory, while KLEMP and DURRAN (1987) showed, in their numerical simulations, that the wave overturning is the principal mechanism of bora flows. Although hydraulic theory holds for most bora cases, there is evidence that some bora cases, occurring mostly in the southern Adriatic, can not be described by it, rather, that downstream effects make the major part in bora genesis due to the isallobaric component of the ageostrophic motion (IvANČAN-PICEK and TUtIš 1996).

There are numerous studies related to bora wind, e.g. JuRČEC (1981), Tutiš and IvanČAn-PiceK (1991), JuRČEC and BRzović (1995). Several recent numerical studies deal with bora in 3D, e.g. Belušić and KLAIĆ (2004), Ivatek-Šahdan and Tudor (2004), Kraljević and Špoler Čanić (2005). Belušić et al. (2004) successfully related quasi-periodic pulsations of observed wind speeds that exist in many bora cases with the conditions in the upper troposphere. GruBIšıć (2004) addressed potential vorticity due to bora at the eastern Adriatic using airborne measurements and numerical modeling, all related to MAP (e.g. BougEAult et al. 2001).

A principal parameter for describing bora-like flows is a Froude number, $F r$, defined as: 
where $U, N$ and $h$ are the background wind speed, buoyancy frequency and the maximum obstacle height respectively. For $F r<1$ the flow is in the nonlinear regime and wave-breaking may occur. If the upstream flow is subcritical, $F r<1$, and the flow reaches criticality around the top of the obstacle, $F r \rightarrow 1$, it becomes supercritical, $F r>1$, on the lee side and accelerates. After being accelerated, the flow returns to the subcritical regime, suddenly decelerating and producing a hydraulic jump while adjusting to the environmental conditions.

ENGER and GRISOGONo (1998; henceforth EG98) showed in 2D simulations that a sea surface temperature (SST) in the lee of the mountain affects the propagation of the bora front and the related hydraulic jump. They relate this effect to maintaining the flow supecriticality by lowering the local buoyancy frequency; moreover, they indicate the importance of Rossby number finiteness (i.e. Coriolis force importance). SKYLLINGSTAD (2005) did LES simulations of the boundary layer evolution in offshore flow of warm air over cool water but did not address the effects of SST on the downslope wind. Needless to say, there is very little known about SST effects on 3D bora-like flows; this hints the goal of this study.

Grisogono and Enger (2004; henceforth GE04) studied a nonlinear flow around an elongated mountain and found that, in the presence of Coriolis forcing, a so called double resonance phenomenon (wave breaking with differential vertical deflections off the flanks) may occur in the lee, causing vigorous asymmetric eddies and low-level jets (LLJs). These eddies may interact with the lee-side bora-like flow, thus affecting the propagation of the bora front and modifying the location of the hydraulic jump as well as the overall atmospheric boundary layer (ABL). The vorticity and divergence due to wave breaking is more than doubled and stretching vigorously in the lee when the Coriolis force is included, all because of the strong coupling between synoptic and mesoscale. 
The aim of this study is to determine the impact of both SST and the eddies on bora evolution; hence, this is a superposition of EG98 and GE04 studies. With respect to the former, here we perform 3D simulations, with respect to the later, here we vary the lee-side temperature, i.e. the SST. This is an expanded and more elaborated version of KRALJEVIC and GRISOGONO (2005) and their tentative results. The emphasis here is on the bora front propagation in 3D, all under the presence of SST variations and the Coriolis effect.

\section{MODEL}

A Coupled Ocean/Atmosphere Mesoscale Prediction System - COAMPS(TM) (Hodur 1997), a nonhydrostatic fully compressible, local area mesoscale numerical model with a terrain influenced height based vertical coordinate is used. The model is used in many idealized simulations, e.g. BuRK et al. (2003), Doyle and Durran (2002), and real case studies e.g. Jiang et al. (2005), Grubišić (2004), Tuernström at al. (2004). The following model setup is as close as possible to that in GE04.

Horizontal dimensions of the computation domain are 250x100 grid points with grid spacing in the $x$ and the $y$ direction of $2.5 \mathrm{~km}$ and $5 \mathrm{~km}$ respectively. The time step of $7.5 \mathrm{~s}$ is employed to ensure the linear stability criterion is met (e.g. DurRan 1999). The model top is set at $15 \mathrm{~km}$ and 35 vertical levels are used with the maximum resolution of $20 \mathrm{~m}$ near the surface. Vertical resolution changes log-linearly from $20 \mathrm{~m}$ at the bottom to $500 \mathrm{~m}$ at around $1 \mathrm{~km}$ above which is kept constant. A $4^{\text {th }}$ order Runge-Kutta advection scheme is used. The fixed lateral boundary conditions are used in the $x$ direction and the extrapolation boundary conditions in the $y$ direction. There is a sponge layer located at the uppermost $4 \mathrm{~km}$ to prevent spurious reflections from the model top. The Mellor-Yamada level 2.5 (Mellor and Yammada 1974) turbulence closure scheme is employed. No explicit numerical diffusion is used. No radiation scheme is used in order to 
remove the diurnal cycle and to keep the simulations as simple as possible. Surface fluxes are set to not affect ground temperature and ground humidity (and vice versa) in order to remove nonlinear effects of thermal interaction between the air and the ground.

An elongated idealized mountain is given by the half-length $L_{y}=50 \mathrm{~km}$ perpendicular to the flow, the maximum height is $H=1000 \mathrm{~m}$ along $x_{0}=-10 \mathrm{~km}$ (75 grid points). In the $x$ direction the mountain is represented by a half Gaussian ridge with half width equal to $L_{x}=10 \mathrm{~km}$ that is cut off on the lee side. Sea resides immediately east of the mountain from $x>0 \mathrm{~km}$. The mountain is given by the following relations:

$$
\begin{gathered}
h(x, y)=H \exp \left\{-\left[\frac{x-x_{0}}{L_{x}}\right]^{2}\right\} ; x<x_{0},-L_{y} / 2<y<L_{y} / 2 \\
h(x, y)=H \exp \left\{-\left[\frac{x-x_{0}}{L_{x}}\right]^{2}-\left[\frac{|y|-L_{y} / 2}{L_{y} / 2}\right]^{2}\right\} ; x<x_{0} \text {, - elsewhere } \\
h(x, y)=H\left(\frac{x_{0}-x}{L_{x}}-1\right), x>x_{0},-L_{y} / 2<y<L_{y} / 2 \\
h(x, y)=H \exp \left[-\left(\frac{|y|-L_{y} / 2}{L_{y} / 2}\right)^{2}\right]\left(1-\frac{x-x_{0}}{L_{x}}\right), x_{0}<x<x_{0}+L_{x}, y-\text { elsewhere } \\
h(x, y)=0, x>x_{0}+L_{x}
\end{gathered}
$$

The background flow is a constant westerly, $U_{0}=8 \mathrm{~m} \mathrm{~s}^{-1}$. The flow is stably stratified with a constant vertical temperature gradient of $5 \mathrm{~K} \mathrm{~km}^{-1}$ which yields a buoyancy frequency $N=0.0132 \mathrm{~s}^{-1}$. These values are chosen to ensure the nonlinearity of the flow regime by providing Froude number $F r=0.6$. The zero-level air temperature is set to $280 \mathrm{~K}$ for simplicity, and is kept constant throughout the simulation. The primary hydrostatic orographic wave has a vertical wavelength $\lambda_{z}=2 \pi H F r=3768 \mathrm{~m}$. With the chosen vertical resolution the wave is represented with 7 grid points in the middle troposphere which should be sufficient to prevent a significant wave distortion due to e.g. aliasing. For the case with $F r=1.2$, buoyancy frequecy is reduced to $N=0.0066 \mathrm{~s}^{-1}$ and the model top is lifted to $22.6 \mathrm{~km}$ and vertical resolution above $1.5 \mathrm{~km}$ is set to $750 \mathrm{~m}$ since the primary hydrostatic orographic wave for this case has a vertical wavelength $\lambda_{z}=2 \pi H F r=7536 \mathrm{~m}$. The thicknes of the sponge layer for this case is $6 \mathrm{~km}$. 
The Coriolis parameter is constant throughout the domain with its magnitude corresponding to the latitude of $45^{\circ} \mathrm{N}\left(f=10^{-4} \mathrm{~s}^{-1}\right)$, this leads to the Rossby radius $L r=1.5 U / f=120 \mathrm{~km}$. This $L r$ is comparable to the width of the mountain which can lead to a type of flow resonance described in GE04. Specific humidity is set to $3 \mathrm{~g} \mathrm{~kg}^{-1}$ at the bottom and linearly decreasing to almost 0 at the model top. Water vapor never approaches saturation and behaves nearly like a passive tracer or flow marker. The surface roughness, $\mathrm{z}_{0}$ is set to $0.01 \mathrm{~m}$ for land and $0.00025 \mathrm{~m}$ for the sea. In the control run SST was set to $280 \mathrm{~K}$. One test was made with buoyancy frequency $N=0.0066 \mathrm{~s}^{-1}$ so that the impact of stability can be stimated. Five sensitivity tests were made with SST set to $270 \mathrm{~K}, 282.5 \mathrm{~K}, 285 \mathrm{~K}, 287.5 \mathrm{~K}$ and $290 \mathrm{~K}$ in order to estimate the impact of the change in SST to the propagation of the bora front. This makes a total of seven idealized simulations to be discussed.

\section{RESULTS AND DISCUSSION}

The model is run for $25 \mathrm{~h}$ but most of the results are discussed at $20 \mathrm{~h}$ in order to be able to compare the results with those in GE04 and other similar studies. In one case the model was run for $35 \mathrm{~h}$ and did not exhibit a completely steady state, but typically a quasi-steady state is reached in less than $15 \mathrm{~h}$ of integration; $20 \mathrm{~h}$ equals to 57.6 dimensionless time units $\left(=U t_{\max } / L_{x}\right)$ which makes results comparable to GE04.

\subsection{Control run}

The control run, obtained with SST equal to zero level air temperature $(S S T=T(z=0)=280 \mathrm{~K})$, is discussed first. The axis for all the figures shown are chosen so that $x=0$ is at the shoreline, while $y=0$ is through the center of the mountain going from west to east. Fig. 1. displays the main flow structure. A 
horizontal cross section of horizontal wind speed at height $z=400 \mathrm{~m}$ is shown in Fig. 1(a). It is clear that the flow is asymmetric around $y=0 \mathrm{~km}$. There are two LLJs extending from both mountain flanks, and a wake directly downstream from the mountain. The northern LLJ is more pronounced than the southern one, as expected. Wind speeds in the northern LLJ reach $12-14 \mathrm{~m} \mathrm{~s}^{-1}$ while those in the southern LLJ are somewhat lower and reach up to $12 \mathrm{~m} \mathrm{~s}^{-1}$. This agrees with the findings of GE04. The velocity gradients are stronger at the northern flank which is also consistent with GE04. Both LLJs have their maxima around $200 \mathrm{~m}$, Fig. 1 (b). On the vertical cross section of horizontal wind speed and potential temperature perpendicular to the flow $15 \mathrm{~km}$ downstream from the shoreline, Fig. 1(b), isentropes generally rise from the south to north, with increasing wind speed and shear, thus lowering Richardson numbers toward north, which is also in agreement with GE04.

A signature of the shooting flow is seen in Fig. 1(a) as the area of strong wind speed gradient immediately in the lee of the mountain. On the horizontal cross section of TKE at $z=400 \mathrm{~m}$ there is an area of increased TKE downstream of the mountain, Fig. 1(c). This is the region of high wind shear located immediately above the shooting flow. The maximum values of TKE reach $6 \mathrm{~m}^{2} \mathrm{~s}^{-2}$. Turbulence in this region (at $z=400 \mathrm{~m}$ ) is not nearly constant, as suggested by EG98, rather it exhibits unsteady behavior without any noticeable periodicity (not shown). Such variation in the two results may arise from the model differences, but it is more likely due to 3D effects considered here. Other horizontal TKE inhomogeneities seen in Fig. 1 (c) relate to the presence of the Earth rotation (GE04); the lee-side ABL is horizontally inhomogeneous due to the differences in the LLJs, and consequently, due to the asymmetry of the lee-side eddies. The shooting flow can best be seen on the vertical cross section of wind speed and potential temperature along the mean flow at the center of the mountain, Fig. 1(d), as the region with isentropes closely packed together and increased wind speeds. The shooting flow develops on the lee-slope of the mountain with wind speeds reaching $15 \mathrm{~m} \mathrm{~s}^{-1}$, Fig. 1(d), which is almost twice the background wind speed, in contrast three times the 
background wind speed found in 2D case in EG98. The hydraulic jump is clearly visible in Fig. 1(d) as the region of steeply rising isentropes. There is a front, related to the abrupt slowdown of the shooting flow through the hydraulic jump. The direction of the mean flow also changes on passing the front. In general the flow turns southward, except on the northernmost part of the obstacle where the flow turns northward. The change in the direction is more pronounced further away from the centerline of the obstacle (not shown). This bora front can be seen in Fig. 1(d) as the region of the strong horizontal wind speed gradient in the lee of the mountain. Now we believe that there is enough similarity and correspondence between this control run and the one in GE04; therefore, we proceed with analyzing simple variations from the control run just described.

\subsection{Sensitivity tests}

Besides the control run, six additional runs were made: one differing in prescribed stability and consequently in Froude number, $F r=1.2$, and five differing only in the prescribed SST in order to determine the effects of the SST on the propagation of the bora front. The difference between zero-level land surface temperature and SST in the runs to be discussed is $\Delta \mathrm{ST}=-10 \mathrm{~K}, 2.5 \mathrm{~K}, 5 \mathrm{~K}, 7.5 \mathrm{~K}$ and $10 \mathrm{~K}$. Here, the differences between the control run and the sensitivity tests are considered. The case with $F r=1.2$ is discussed first. No figures for this simulation are shown, only the main results are described.

For $\mathrm{Fr}=1.2$ the flow is in nearly linear regime (weekly nonlinear) so there is no wave-breaking and consequent shooting flow and/or hydraulic jump. There are no LLJs on the flanks of the mountain and there is no wake downstream of the area of the shooting flow. There is a LLJ directly downstream with the wind speeds exceeding $14 \mathrm{~m} \mathrm{~s}^{-1}$. It extends over $25 \mathrm{~km}$ off shore, reaches up to $600 \mathrm{~m}$ having the core between 200 and $400 \mathrm{~m} \mathrm{AGL}$. The area of increased turbulence is moved further downstream than in the control run, having the maximum between 20 and $40 \mathrm{~km}$ off shore, but its intensity is much lower $\left(<0.5 \mathrm{~m}^{2} \mathrm{~s}^{2}\right)$ than in the 
control run. Needless to say, strong nonlinear effects, i.e. wave breaking, are the key mechanism in obtaining bora like hydraulic flow, as was demonstrated by KLEMP and DuRRAN (1987), so these results are in accord with the expectations.

Using SST lower than the zero-level land surface temperature produces a higher pressure over the sea; the related flow structure is shown in Fig. 2. Also, cooling of the lower ABL increases a vertical temperature gradient thus further stabilizing the flow. This strengthens the LLJs as seen by comparing Fig. 2(a) with 1(a) and Fig. 2(b) with Fig. 1(b). The shooting flow is more shallow than in the control run, which is indicated by a smaller region of increased TKE at $z=400 \mathrm{~m}$ immediately downstream of the mountain, Fig. 2(c), over the shooting flow, the maximum values of TKE are the same as in the control run. The hydraulic jump and the bora front are located above the shoreline since there is no propagation of the shooting flow over the sea, Fig. 2(d). This corresponds to a summertime situation.

When the SST is set to be higher than the zero-level land surface temperature, a lower pressure develops over the sea, Fig. 3. Also, stability is decreased due to the heating of the lower ABL which weakens the vertical temperature gradient. This leads to the narrowing of the downstream wake, Fig 3(a). The area of the northern LLJ is increased while the area of the southern LLJ is slightly reduced (compare the areas inside the $10 \mathrm{~m} \mathrm{~s}^{-1}$ isotache at the northern and the southern flank of the mountain of Fig. 1(a) and Fig. 3(a)). The greatest difference in the LLJs between the case with higher SST and the control run is seen by comparing Fig. 3(b) and Fig. 1(b). The maximum wind speeds that occur in the LLJs are lower than in the control run; here they barely reach to $14 \mathrm{~m} \mathrm{~s}^{-1}$. However, the vertical extent of the LLJs is increased, Fig 3(b), through a more efficient mixing, enhanced by the largest SST considered here. Horizontal wind shear between the wake and the LLJs is lower which, as will be discussed later, has the important consequences on the bora front.

Horizontal cross section of TKE at $z=400 \mathrm{~m}$, Fig. 3(c), shows that the area of increased TKE 
( $>1 \mathrm{~m}^{2} \mathrm{~s}^{-2}$ ) extends up to $20 \mathrm{~km}$ from the shore indicating significant wind shear beneath. In contrast to the control run shown in Fig. 1(d), the shooting flow here is enhanced, extending well out over the sea, Fig. 3(d). The maximum wind speeds exceed $16 \mathrm{~m} \mathrm{~s}^{-1}$ and the shooting flow stretches approximately $11 \mathrm{~km}$ out over the sea. The maximum wind speeds occur at around $100 \mathrm{~m}$. The hydraulic jump is seen in Fig. 3(d) as the region of rising isentropes between 6 and $12 \mathrm{~km}$ from the shoreline in contrast with Fig. 1(d) where the hydraulic jump is located just above the shoreline. Above the hydraulic jump at approximately $400-800 \mathrm{~m}$, south from the centerline, there is a region of northerly flow parallel to the mountain with wind speeds of approximately $3 \mathrm{~m} \mathrm{~s}^{-1}$; north from the centerline the flow is south-easterly and the observed wind speeds are less than $2 \mathrm{~m} \mathrm{~s}^{-}$

${ }^{1}$. These winds relate to the lee-side eddies and a weak sign of a sort of mountain-parallel LLJ (much weaker than in EG98). Comparing Figs. 1(d)-3(d) one concludes that the warming of the lee-side ABL decelerates the lee-side wind much more efficiently than the equivalent cooling accelerates this wind. These simulations with SST $>0$ relate to wintertime situations when the bora is usually more vigorous than during summers.

\subsection{Bora front propagation}

In this subsection we discuss the offshore propagation of the bora front in regard to the change of SST. In order to do this, we subjectively define the location of this front, namely, the bora front as the maximum extent of the $1.2 U_{0}$ isotache, as in EG98. This particular issue, i.e. the bora front offshore propagation, is very important in coastal oceanography because it affects the curl of the stress which drives a sea surface flow (e.g. ORLIĆ et al.). The bora offshore extent generally weakens with the offshore distance; this decrease can sometimes be very abrupt in both space (e.g. Grubišrć 2004) and time (e.g. Belušlć et al. 2005). For strong bora cases, its extent out over $10-20 \mathrm{~km}$ offshore is consistent with our findings, so it is the authors opinion that this idealized study is relevant regarding the real bora flow.

The front is unsteady in time, it seems as it oscillates moving back and forth as can be seen in Fig. 4 . 
Whether this bora front motion is quasi-periodic or not, can not be determined due to shortness of the model integration time; this will be a scope of another study dealing with time scales spanning from the Coriolis period to fast pulsations as in Belušić et al. (2004). Additional complexity comes from the fact that the front does not vibrate parallel to the shoreline either, but it is doing so closer to the mountain on its northern side, Figs 4. and 5. This can be connected with the lee-side vortices that may somewhat twist and tilt the bora front, thus affecting the offshore propagation of the front. Those vortices are asymmetric, the northern being more vigorous than the southern one as also indicated by GE04. Generally, the front vibrations are more pronounced at the southern flank of the mountain where the LLJ is weaker. With the increase of SST the vibrations become more irregular. The greatest amplitudes occur at the southern flank of the mountain, Fig. 4 (a); also, the vibrations are more regular there.

With SST lower or equal to land surface temperature there is some offshore propagation of the bora front only at the southern flank of the mountain ( 5 and $7 \mathrm{~km}$ for $\Delta \mathrm{ST}=-10 \mathrm{~K}$ and $0 \mathrm{~K}$ respectively), while along the centerline and $25 \mathrm{~km}$ to the north, the propagation is minimal, Fig. 5. This is in accordance to EG98, who found no propagation for $\Delta \mathrm{ST} \leq 0$. As $\Delta \mathrm{ST}$ grows so does the distance of the bora front location from the shoreline, Fig 5. The front reaches the maximum offshore distance for the maximum $\Delta \mathrm{ST}-11 \mathrm{~km}$ for $\Delta \mathrm{ST}=10 \mathrm{~K}$. Nonetheless, this is seven times lower than the distance obtained by EG98; hence, this result stresses the importance of the interaction between the hydraulic jump and lateral, orographically induced, eddies. The slopes of the lines in Fig. 5. indicate that there is some "saturation temperature" after which a further increase in $\Delta \mathrm{ST}$ will yield no further offshore propagation of the bora front. This is also in contrast with EG98 who found no such effect. Hence, Fig. 5 displays some of the most important results of this study.

The tilt of the bora front also changes with $\Delta \mathrm{ST}$. For $\Delta \mathrm{ST} \leq 0$ the front is further away from the shoreline at the southern flank of the mountain than at the northern flank, Fig. 5, but this distance grows with the increase of $\Delta \mathrm{ST}$ more quickly on the centerline and at the northern flank; consequently for $\Delta \mathrm{ST}>5 \mathrm{~K}$ the 
maximum extent of the front is at the centerline. Asymmetric lee-side vortices may somewhat tilt and twist the bora front, thus affecting the offshore propagation of the front. This is connected with the increase of mixing and weakening of eddies at the northern edge of the wake by the increase in $\Delta \mathrm{ST}$, which allows the bora front to move further off shore (compare Figs 1(b)-3(b)).

\section{CONCLUSIONS}

We have examined the manner in which the difference between lee-side SST and the zero-level land surface temperature affects bora-like flows. We did this by performing many and showing six 3D idealized simulations that differ in SST only, using a COAMPS (TM) nonhydrostatic mesoscale model. This study is motivated by understanding of the behavior of the bora wind at the eastern Adriatic coast, its dynamics and seasonal variations, and it continues on the studies of EG98 and GE04. While Fig. 1 illustrates the overall flow configuration and setup addressed here, Fig. 5 summarizes our main findings about lee-side temperature effects onto bora flows. The SST affects the bora flow characteristics - the LLJ and the bora front propagation. Orographically generated vortices modify the shape of the bora front which is found not to be parallel with the shoreline. The increase in $\Delta \mathrm{ST}$ reduces horizontal wind shear (enhanced mixing) and weakens eddies on the north edge of the wake, which allows the bora front to propagate further off shore which, in turn, reduces the tilt of the bora front. It is found that the front is unsteady in time, it moves back and forth, with the vibrations more pronounced at the southern flank of the mountain where the LLJ is weaker; also, the vibrations become more irregular with the increase of SST.

The bora front offshore propagation is much weaker (up to seven times) than indicated by findings for a 2D case in EG98. Also, it is found here that the relation between the increase of SST and the increase of the 
distance of the bora front offshore propagation is not linear, as was suggested in 2D study of EG98, but the propagation of the front diminishes after a certain increase of SST. In other words, there is a saturation in the relation between the offshore bora front propagation and the SST increase.

\section{Acknowledgment}

We thank to Leif Enger of Uppsala University for his comments and suggestions. This study was supported by the Ministry of Science, Education and Sports of the Republic of Croatia (grant: 0119339). This study is partly supported by Hydrological and Meteorlogical Service of Croatia which also provided the computational resorces. Annonymous reviewers are thanked for their valuable suggestions. Georg Pistotnik is thanked for translating the abstract to german.

\section{REFERENCES}

Belušić, D., Z.B. Klaić, 2004: Estimation of bora wind gusts using a limited area model. - Tellus 56A, 296307.

Belušić, D., M. Pasarić, M. Orlić, 2004: Quasi-periodic bora gusts related to the structure of the troposphere.

- Q. J. R. Meteorol. Soc. 130, 1103-1121.

Bougeault, P., P. Binder, A. Buzzi, R. Dirks, R. Houze, J. Kuettner, R.B. Smith, R. Steinacker, and H. Volkert, 2001: The MAP Special Observing Period. - Bull. Amer. Meteorol. Soc. 82, 433-462.

Burk, S.D., T. Haack, L.T. Rogers, L.J. Wagner, 2003: Island wake dynamics and wake influence on the evaporation duct and radar propagation. - J. Appl. Meteorol. 42(3), 349-367.

Doyle, J.D., D. R. Durran 2002: The dynamics of mountain-wave-induced rotors. J. Atmos. Sci. 59, 186-201. 
Durran, D. R. 1986: Another look at downslope windstorms. Part I: The development of analogs to supercritical flow in an infinitely deep continuously stratified fluid. - J. Atmos. Sci. 43, 2527-2543.

Durran, D. R. 1999: Numerical Methods for Wave Equations in Geophysical Fluid Dynamics. SpringerVerlag, New York, USA.

Durran, D.R. 2003: Downslope winds. Pp. 644-650 in Encyclopedia of atmospheric sciences. Eds. J. R. Holton, J. A. Curry and J. A. Pyle. Academic Press, London, UK.

Enger, L., B. Grisogono, 1998: The response of bora-type flow to the sea surface temperature. - Q. J. R. Meteorol. Soc. 124, 1227-1244.

Grisogono, B., L. Enger, 2004: Boundary-layer variations due to orographic-wave breaking in the presence of rotation. - Q. J. R. Meteorol. Soc. 130, 2991-3014.

Grubišić V., 2004: Bora-driven potential vorticity over Adriatic. - Q. J. R. Meteorol. Soc. 130, 2571-2603.

Hodur, R. M. 1997: The naval research laboratorys coupled ocean/atmosphere mesoscale prediction system (COAMPS). - Mon. Wea. Rev. 125(7), 1414-1430.

Ivančan-Picek, B., V. Tutiš, 1996: A case study of a severe Adriatic bora on 28 December 1992. - Tellus 48A, 357-367.

Ivatek-Šahdan, S., M. Tudor, 2004: Use of high-resolution dynamical adaptation in operational suite and research impact studies. - Meteorol. Z. 13(2), 99-108.

Jiang, Q.F., J.D. Doyle, R.B. Smith, 2005: Blocking, descent and gravity waves: Observations and modeling of a MAP. - Q. J. R. Meteorol. Soc. 131, 675-701.

Jurčec, V 1981: On mesoscale characteristics of Bora conditions in Yugoslavia. - Pure and KraljevićAppl. Geophys. 119, 640-657.

Jurčec V, N. Brzović, 1995: The Adriatic bora: special case studies. - Geofizika 12, 15-32.

Klemp, J.B., D.R. Durran, 1987: Numerical modeling of bora winds. - Meteorol. Atmos. Phys. 36, 215-227. 
Kraljević, L., B. Grisogono, 2005: Sea-surface temperature effects on 3D bura like flow. - Cro. Meteorol. J. 40, 288-291.

Kraljević, L., K. Špoler Čanić, 2005: High resolution simulation of a severe bura event. - Cro. Meteorol. J. 40, 292-295.

Mellor, G.L., T. Yamada, 1974: A hierarchy of turbulence closure models fot planetary boundary layers. - J. Atmos. Sci. 31, 1791-1806.

Poje, D. 1992: Wind persistence in Croatia. - Intl. J. Clim. 12, 569-586.

Orlić, M., M. Kuzmić, Z. Pasarić, 1994: Response of the Adriatic sea to the bora and sirocco forcing. Continental Shelf Res. 14, 91-116.

Skyllingstad, E.D., R. M. Samelson, L. Mahrt, P. Barbour, 2005: A Numerical Modeling study of warm offshore flow over cool water. - Mon. Wea. Rev. 133, 345-361.

Smith, R. B. 1985: On severe downslope winds. - J. Atmos. Sci. 42, 2597-2603.

Smith, R. B. 1987: Aerial observations of the Yugoslavian bora. - J. Atmos .Sci. 44, 269-297.

Smith, R. B. and Sun, J. 1987: Generalized hydraulic solutions pertaining to severe downslope wind flow. - J. Atmos. Sci. 44, 2934-2939.

Tjernström, M., M. Žagar, G. Svensson 2004: Model simulations of the Arctic atmospheric boundary layer from the SHEBA year. - Ambio, 33, 221-227.

Tutiš, B., B. Ivančan-Picek, 1991: Pressure drag on the Dinaric Alps during the ALPEX SOP. - Meteorol. and Atmos. Phys. 47, 73-81. 

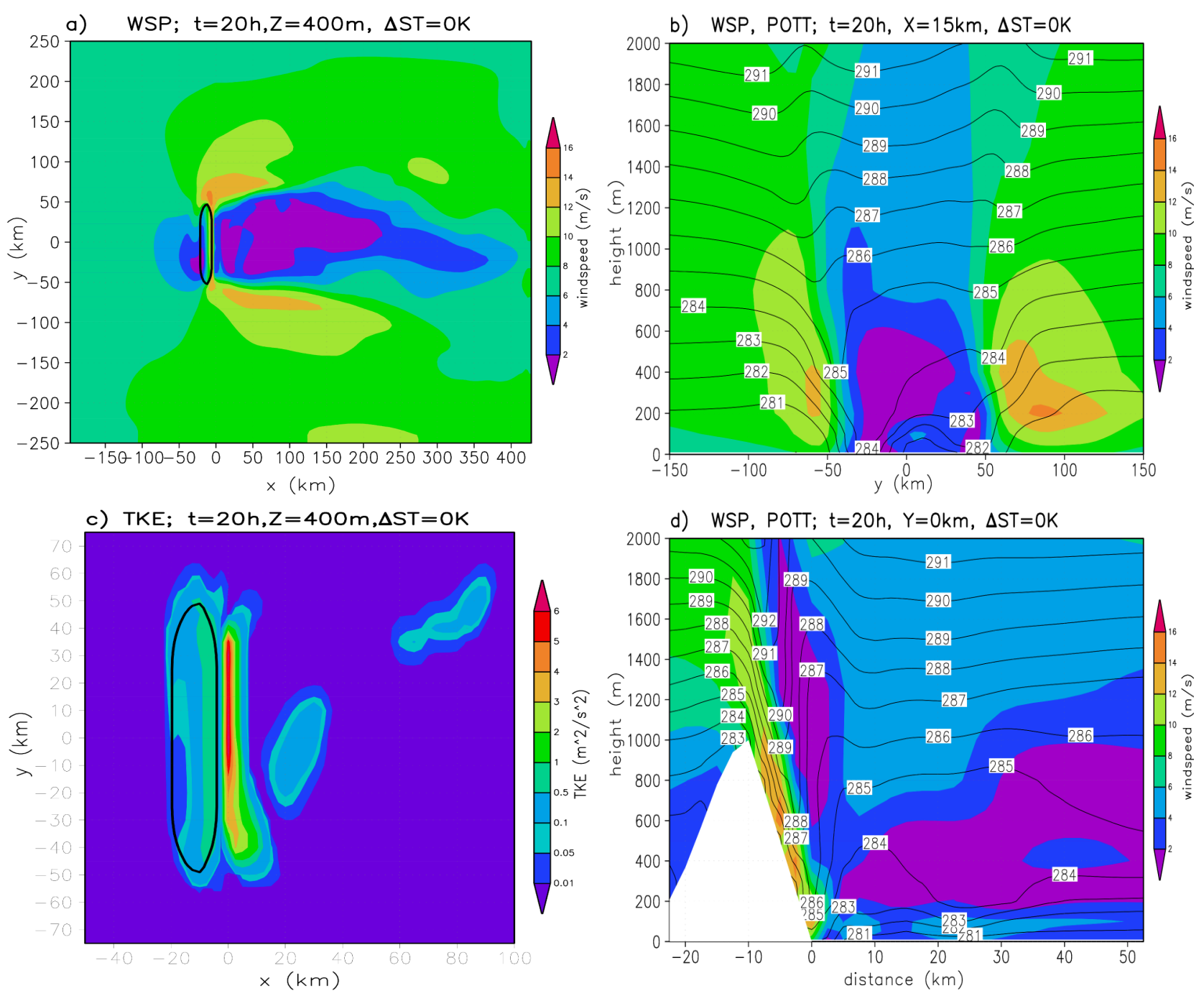

$\times(\mathrm{km})$

Figure 1. The control run fields $(\Delta \mathrm{ST}=0)$ after $20 \mathrm{~h}$ of integration, sea at $x>0$, mountain centerline at $y=0$ : (a) horizontal wind speed $\left(\mathrm{m} \mathrm{s}^{-1}\right)$ at height $z=400 \mathrm{~m}$, wind speed color range is from 2 to $14 \mathrm{~m} \mathrm{~s}^{-1}$ by $2 \mathrm{~m} \mathrm{~s}^{-1}$ increment; (b) horizontal wind speed $\left(\mathrm{m} \mathrm{s}^{-1}\right)$-in color and potential temperature $(\mathrm{K})$ - contours at $x=15 \mathrm{~km}$ from the shoreline perpendicular to the mean flow, wind speed color range is from 2 to $14 \mathrm{~m} \mathrm{~s}^{-1}$ by $2 \mathrm{~m} \mathrm{~s}^{-1}$ increment, isentrope increment $1 \mathrm{~K} ;(\mathrm{c})$, TKE $\left(\mathrm{m}^{2} \mathrm{~s}^{-2}\right)$ at height $\mathrm{z}=400 \mathrm{~m}$, color increments $0.01,0.05,0.1,0.5,1,2,3,4,5,6 \mathrm{~m}^{2} \mathrm{~s}^{-2} ;(\mathrm{d})$ horizontal wind speed $\left(\mathrm{m} \mathrm{s}^{-1}\right)$-in color and potential temperature $(\mathrm{K})$ - contours through center of the mountain $\left(y=0 \mathrm{~km}\right.$ ) along the mean flow, wind speed color range is from 2 to $14 \mathrm{~m} \mathrm{~s}^{-1}$ by $2 \mathrm{~m} \mathrm{~s}^{-1}$ increment, isentrope increment $1 \mathrm{~K}$. 

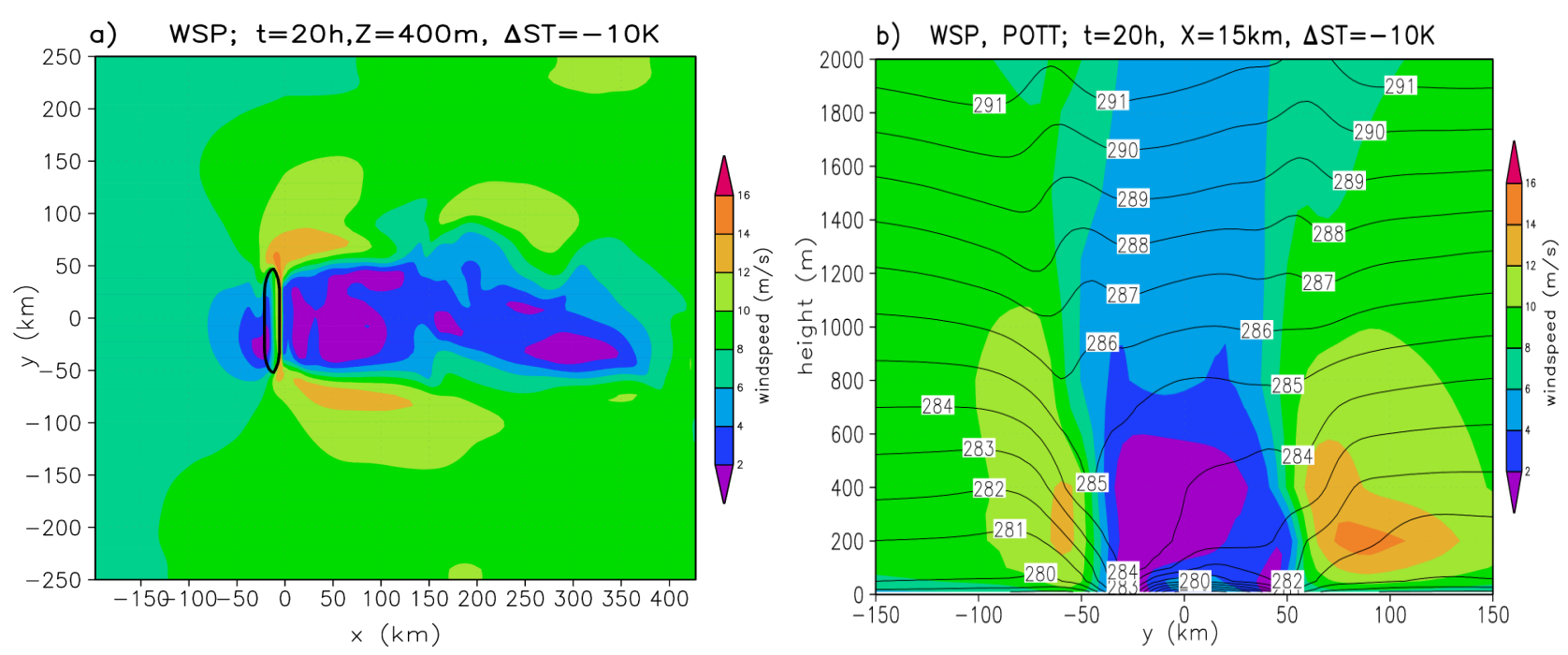

c) TKE; $t=20 \mathrm{~h}, \mathrm{Z}=400 \mathrm{~m}, \Delta \mathrm{ST}=-10 \mathrm{~K}$
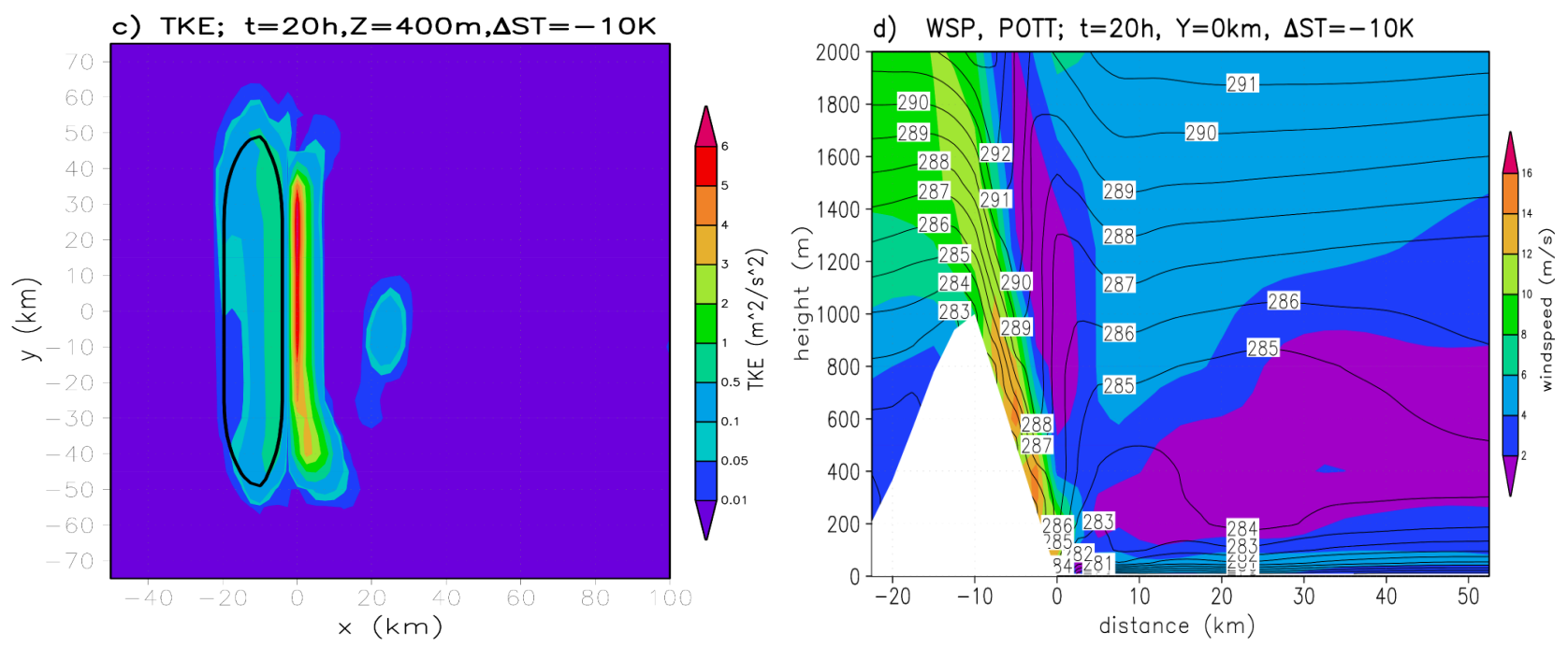

Figure 2. Same as Fig. 1 but the difference between SST and land surface temperature $\Delta \mathrm{ST}=-10 \mathrm{~K}$. 

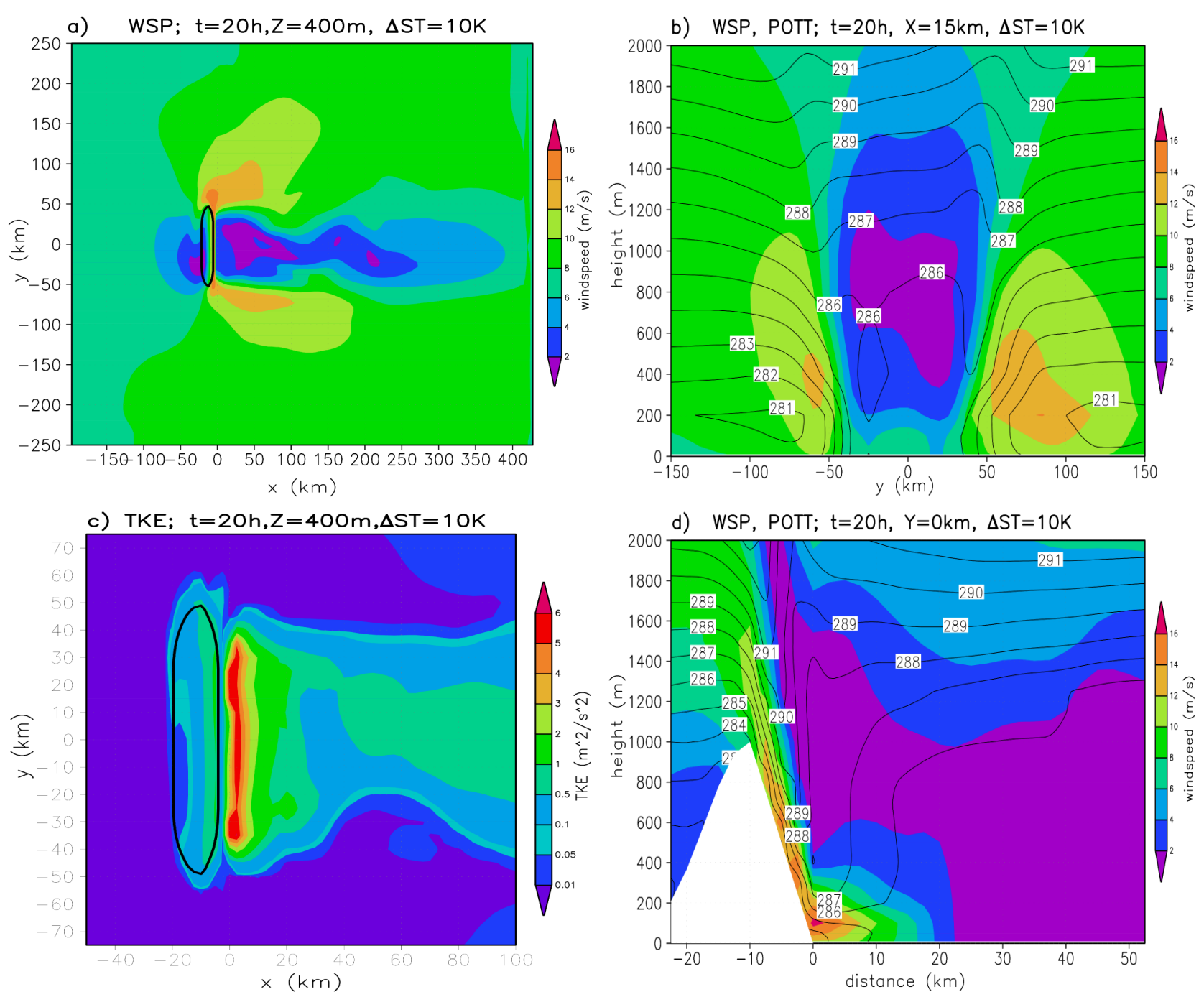

Figure 3. Same as Fig. 1 but the difference between SST and land surface temperature $\Delta \mathrm{ST}=10 \mathrm{~K}$. 
a) $25 \mathrm{~km}$ south of the centerline

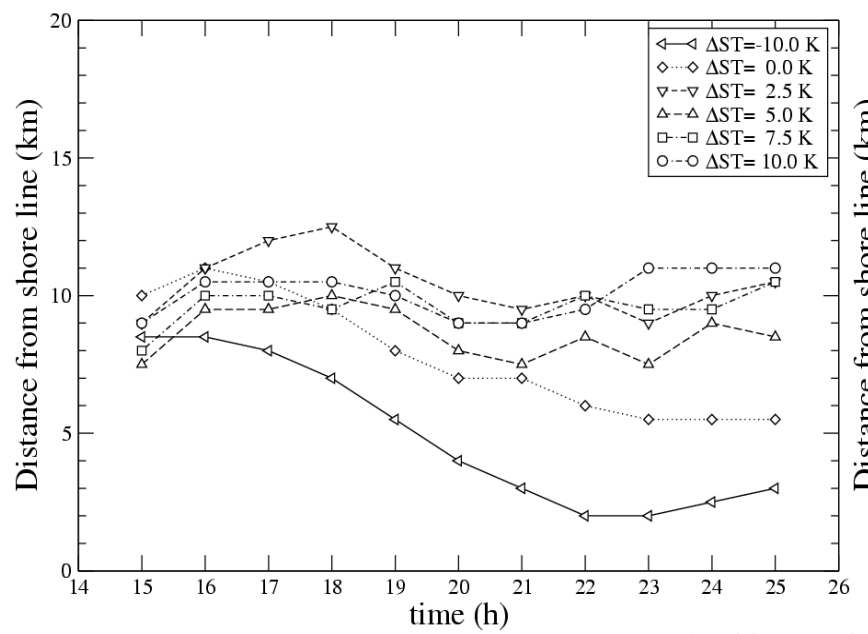

c) $25 \mathrm{~km}$ north of the centerline b) Along the centerline

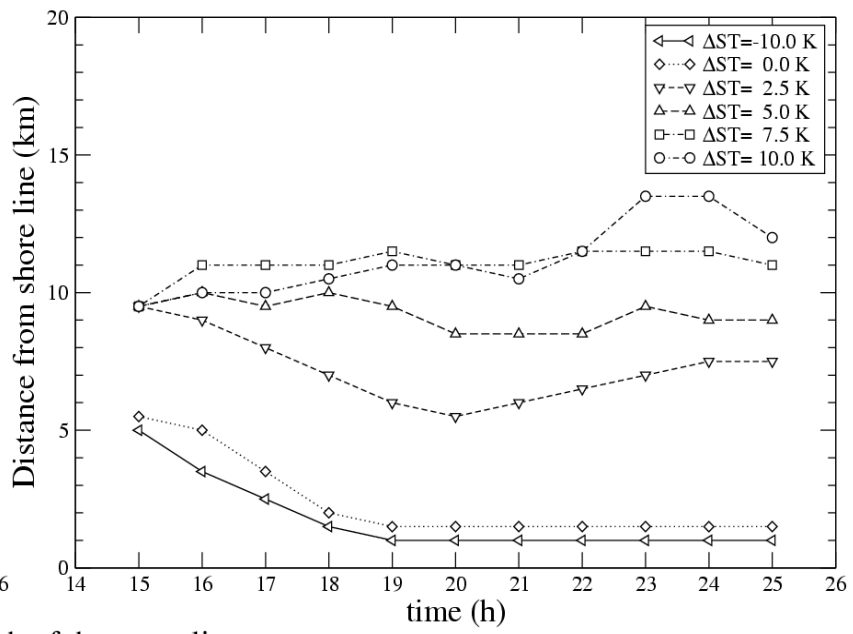

$\frac{1}{4-4 S T=10.0 \mathrm{~K}}$

$\checkmark \Delta \mathrm{ST}=-10.0 \mathrm{~K}$

$\diamond \cdots \diamond \Delta \mathrm{ST}=0.0 \mathrm{~K}$
$\nabla-\nabla \Delta \mathrm{ST}=2.5 \mathrm{~K}$

$\Delta-\triangle \Delta S T=5.0 \mathrm{~K}$

$\Delta-0 \Delta \mathrm{ST}=10.0 \mathrm{~K}$
$0-0 \Delta \mathrm{K}$

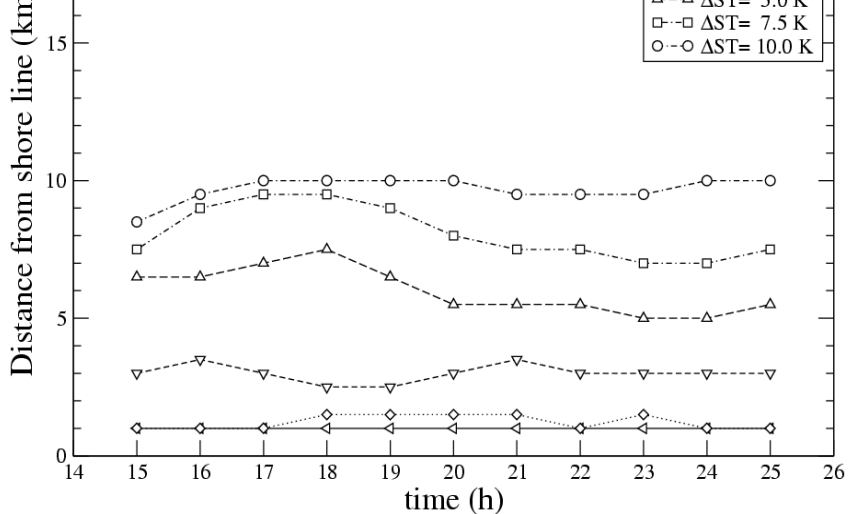

Figure 4. A bora front propagation distance $(\mathrm{km})$ as a function of time (h) for different $\Delta \mathrm{ST}$ : (a) $25 \mathrm{~km}$ north of the centerline of the mountain, (b) along the centerline of the mountain, (c) $25 \mathrm{~km}$ south of the centerline for different $\Delta \mathrm{ST}$. 


\section{Mean distance from the shoreline as a function of SST}

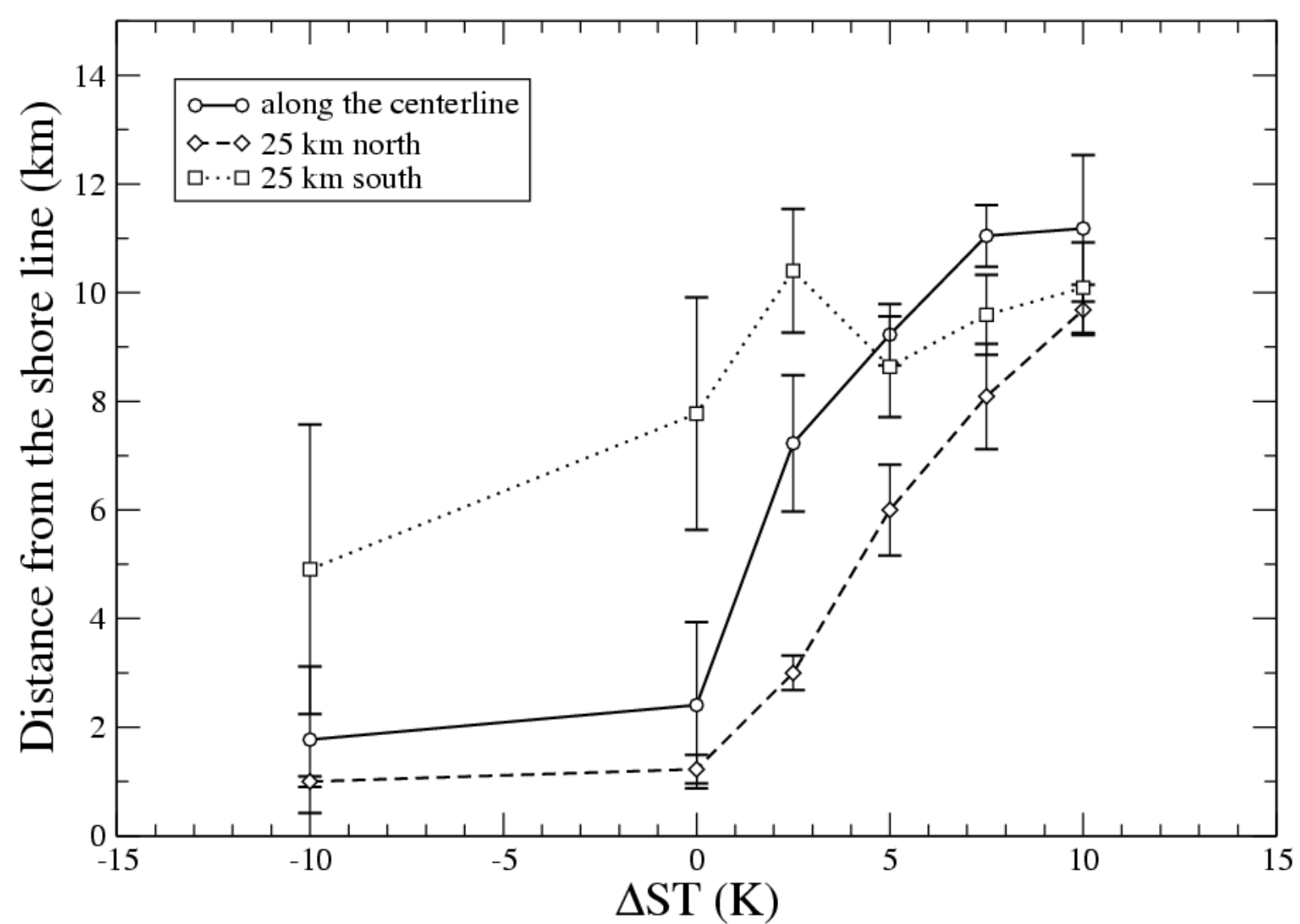

Figure 5. An average bora front propagation distance from shore line $(\mathrm{km})$ as a function of $\Delta \mathrm{ST}$ along the centerline of the mountain (solid), $25 \mathrm{~km}$ to the south (dotted), $25 \mathrm{~km}$ to the north (dashed), Error bars indicate standard deviations. 